\title{
THE BIOINDICATION IMPORTANCE OF THE CARABIDAE COMMUNITIES OF VEPORSKÉ VRCHY AND JUHOSLOVANSKÁ KOTLINA
}

\author{
VLADIMÍR LANGRAF ${ }^{1}$, KORNÉLIA PETROVIČOVÁ ${ }^{1}$, STANISLAV DAVID ${ }^{1}$, JANKA \\ SCHLARMANNOVÁ ${ }^{2}$
}

${ }^{1}$ Department of Ecology and Environmental Sciences, Faculty of Natural Sciences Constantinethe Philosopher University in Nitra, Tr. A. Hlinku 1, Nitra, Slovak Republic; e-mail: vladimir.langraf@ukf.sk, kornelia.petrovicova@ ukf.sk, sdavid@ukf.sk

${ }^{2}$ Department of Zoology and Anthropology, Faculty of Natural Sciences Constantinethe Philosopher University in Nitra, Tr. A. Hlinku 1, Nitra, Slovak Republic; e-mail: jschlarmannova@ukf.sk

\begin{abstract}
Langraf V., Petrovičová K., David S., Schlarmannová J.: The bioindication importance of the Carabidae communities of Veporské vrchy and Juhoslovanská kotlina. Ekológia (Bratislava), Vol. 35, No. 2, p. 126-135, 2016.

The Carabidae family (Coleoptera) is used frequently for its bioindication potential to detect the environmental burden. In 2013 and 2014, we studied the correlation of Carabidae on the biotopes of six areas in the Veporské vrchy Mts and the Juhoslovenská kotlina basin by using pitfall traps, Möricke plates and Bambara beetle traps. Out of 432 recorded specimens of beetles (53 species, 15 families), the Carabidae family were the highest number of species and specimens represented, with which we confirmed higher anthropogenic interference and disturbance of ecosystems in the Juhoslovenská kotlina basin. This statistic confirms the presence of the following species typically found on arable land: Anchomenus dorsalis, Calathus fuscipes fuscipes, Harpalus affinis and Pseudoophonus rufipes. The ecosystems in the Veporské vrchy Mts region show less disturbance, and the anthropological impact is smaller, indicated by the presence of the Carabus problematicus species, an important indicator of the conservation of natural forest ecosystems.
\end{abstract}

Key words: Coleoptera, Carabidae, indicators, biomonitoring, Slovakia.

\section{Introduction}

The Veporské vrchy Mts region and the Juhoslovenská kotlina basin belong to littleresearched areas in Slovakia in terms of knowledge of beetles (Coleoptera). We decided to supplement incomplete coleopterological information with our own research and contribute to a better understanding of investigated beetle territory. The faunistic data obtained was analysed from the perspective of discovered species in correlation to their habitats. The aim being to spread the potential of the bioindication value of carabid beetles. 
Information about the beetles spreading in the Veporské vrchy Mts, the Juhoslovenská kotlina basin and the Cerová vrchovina Mts was published by Franc (1995), who focused on important local species. He conducted his research from 1993 to 1995, at which point the Carabidae family was represented by 22 species. In nearby Muránska planina Mts, Kleinert (1985) recorded 75 carabid species. Data about the Carabidae from the Muránska planina Mts was added by Majzlan (2010), who found 18 species from the Carabidae family during 2003. Vician et al. $(2007,2008,2010,2011)$ explored the different species structure of the Carabidae community in various agriculturally farmed areas of the Zvolenská kotlina basin and the Podpolanie region, recording 47 carabid species within 67 species of beetles.

Bioindicators are organisms that react sensitively to changing factors of the environment and also to the changing structure of phytocenoses (Hůrka, Šustek, 1995). For bioindication, we use species with familiar autecology, which are easy identified and represented in the wide scale of ecosystems (Šteffek et al., 2008, Kalivoda et al., 2010). The Carabidae family is used as a family of beetles with bioindicator potential, for they are a species that live in different types of habitats: forests, meadows, fields and peatbogs (Hůrka, 1996; Igondová, Majzlan, 2015). Carabid beetles also react sensitively to toxic substances (herbicides, insecticides), changes in soil $\mathrm{pH}$ and changes in soil humidity (Hůrka, 1996; Porhajašová et al., 2011; Burgio et al., 2015). Topping et al. (2015) evaluated in his research the impact of toxic pesticide on the landscape with the help of the eurytopic species Bembidion lampros.

Agricultural landscape presents a cultural type of landscape where the progress of material and energy processes are changed and influenced by man. According to the intensity of farming, there is a reduction in the ecosystems' biodiversity on agricultural areas (Vician et al., 2011). Some of Carabid beetles are well adapted to the regime of farming (Lövei, Sunderland, 1996; Vician et al., 2007, 2008). It was discovered using several methods that the intensity of farming influences the species composition of the Carabidae community (Nietupsky et al., 2015). This bioindication potential of the Carabidae is used to detect different intensities of landscape use. Vician et al. $(2010,2011)$ stated that the following species are typically found on ploughland: Clivina fossor, Calathus fuscipes, Amara aenea, Anchomenus dorsalis, Harpalus affinis, $H$. distinguendus and Pseudoophonus rufipes.

In forest ecosystems, carabid beetles react to changes that are derived from the character of the tree layer. The structure of the Carabidae community can change according to the intensity of forest harvesting (Šteffek et al., 2008). Forest harvesting dramatically changes the microclimate and light conditions of the habitat and also the species composition and phenology of the herbaceous community (Halpern et al., 2005). The composition, creation of overlaying humus and amount of dead wood are also changing (Freedman et al., 1996). Destruction of particular microhabitats as a consequence of forest harvesting leads to losing specific forest carabids and their being replaced by eurytopic species (Finch, 2005). Šteffek et al. (2008) considered these changes as a demonstration of ecological degradation of ecosystems, which are connected to anthropogenic activities in the country.

The aim of the paper is faunistic-ecological research into the beetle community in the Veporské vrchy Mts and the Juhoslovenská kotlina Basin. Anthropogenic activity (agriculture, forest harvesting) in the studied area is evaluated by the bioindication of the identified species of the Carabidae family. 


\section{Material and methods}

Beetle research took place in six localities at two-week intervals, totalling 25 times from April until the end of October in years 2013 and 2014. We used pitfall traps (750 ml), Möricke plates (1,500 ml) (Novák et al., 1969) and Bambara beetle trap (1,000 ml) (Hulcr, Mccoy, 2015). We determined the types of biotopes in the localities that accorded to Ružičková et al. (1996). Pitfall traps were arranged at each biotope in a trap line, and each trap line consisted of five pitfall traps (at $5 \mathrm{~m}$ intervals). As a fixation fluid, we used $4 \%$ saline. We determined the obtained material on the basis of identification keys: Balthasar (1957) and Hůrka (1996). Terminology and systematic order of the families, according to Holecová and Franc (2001). Calculation of dominance (D) and frequency (F) and the classification of species into appropriate categories were performed according to Losos et al. (1984). Diversity and equitability was calculated with the program Past 3.5 (Hammer, 2015) using the natural logarithm (ln). We verified the correlation of the species to the biotopes by applying canonical correspondence analysis (CCA) using correlation matrix $\left({ }^{*} \cdot \log \right.$ file), and statistical significance was tested in the Canoco program using the Monte Carlo permutation test (Ter Brak, Šmilauer, 2002). According to the importance $\mathrm{p}_{\alpha}<0.05$, we tested the statistic importance of correlation of the biotops and the species by Spearman's non-parametric correlation coefficient in program Statistika.cz (StatSoft, 2009). The bioindication rating of carabid beetles according to Buchar (1893) is the following:

- $\quad$ Group R - relics, stenotopic species with narrow ecological valence. Mostly rare and endangered species of the natural ecosystems least affected by human activity. Types of peatlands and native forests in arctic-alpine, boreo-alpine and boreo-montane zones,

- Group A - adaptable species inhabiting areas moderately affected by human activity, occurring in secondary, well-regenerated habitats and ecotones. The largest species group of cultural forests, meadows, pastures and non-regulated and natural riparian vegetation,

- Group E - eurytopic species without special demands to the character and the quality of the environment. They occur in fragile and changing biotopes with strong anthropogenic influence such as deforested and open agricultural cultivated landscape as well as urbanised ecosystems. This group also includes expansive species that extend their area or are irregular migrants.

Study area

The study areas are located in the southern part of Slovakia in the geomorphological unit Veporské vrchy Mts and the Juhoslovenská kotlina basin. Location data and biotope characteristics of the localities are presented in Table 1 .

$\mathrm{T}$ a b l e 1. Location data of the study localities and their biotope characteristics.

\begin{tabular}{|c|c|c|c|c|c|c|}
\hline $\begin{array}{c}\text { Geomorphological } \\
\text { unit }\end{array}$ & & Locality & $\begin{array}{c}\text { Cadastral } \\
\text { area }\end{array}$ & m.a.s.l. & Biotope & $\begin{array}{l}\text { Geographic } \\
\text { coordinates }\end{array}$ \\
\hline \multirow{2}{*}{ Veporské vrchy Mts } & 1 & Farkaška & Utekáč & 570 & Culture of Picea abies & $\begin{array}{l}48^{\circ} 36^{\prime} 31^{\prime \prime} \mathrm{N} \\
19^{\circ} 47^{\prime} 38^{\prime \prime} \mathrm{E}\end{array}$ \\
\hline & 2 & Lichovo & Utekáč & 556 & pasture & $\begin{array}{l}48^{\circ} 36^{\prime} 30^{\prime \prime} \mathrm{N} \\
19^{\circ} 48^{\prime} 35^{\prime \prime} \mathrm{E}\end{array}$ \\
\hline \multirow{4}{*}{$\begin{array}{l}\text { Juhoslovenská } \\
\text { kotlina basin }\end{array}$} & 3 & Kúpna hora & Poltár & 300 & Carpathian oak-hornbeam forest & $\begin{array}{l}48^{\circ} 26^{\prime} 09^{\prime \prime} \mathrm{N} \\
19^{\circ} 49^{\prime} 27^{\prime \prime} \mathrm{E}\end{array}$ \\
\hline & 4 & Prievranka & Poltár & 272 & pasture & $\begin{array}{l}48^{\circ} 25^{\prime} 52^{\prime \prime} \mathrm{N} \\
19^{\circ} 49^{\prime} 08^{\prime \prime} \mathrm{E}\end{array}$ \\
\hline & 5 & Ladovo & Lučenec & 258 & Carpathian turkey oak forest & $\begin{array}{l}48^{\circ} 19^{\prime} 08^{\prime \prime} \mathrm{N} \\
19^{\circ} 37^{\prime} 48^{\prime \prime} \mathrm{E}\end{array}$ \\
\hline & 6 & $\begin{array}{l}\text { Vinohradná } \\
\text { rovina }\end{array}$ & Lučenec & 208 & fallow field & $\begin{array}{l}48^{\circ} 19^{\prime} 017^{\prime \prime} \mathrm{N} \\
19^{\circ} 39^{\prime} 05^{\prime \prime} \mathrm{E}\end{array}$ \\
\hline
\end{tabular}

Explanatory notes: m.a.s.l. - metres above sea level. 


\section{Results and discussion}

In the study area, we recorded 432 specimens of beetles belonging to 53 species and 14 families. The highest number of species and specimens that was represented by bioindication was the Carabidae family (Table 2), the species that was represented at the highest frequency class of all biotopes. It is a prerequisite of bioindication to use Carabidae families to determine the quality of the environment. The dominance of the Carabidae family was confirmed by Baranová and Jászay (2010), during their research of epigeic beetles in the mountain forests of Čergov Mts. They recorded 22 families of Coleoptera order, the Carabidae family having the highest species richness (29 in total). During 2002-2004, Porhajašová (2009) found on spring and winter barley fields near the town of Nitra that out of 16 families of beetles discovered, the Carabidae family was the most dominantly represented.

We registered 150 specimens of beetles belonging to 10 families and 23 species in localities 1 and 2 (the Veporské vrchy Mts, Utekáč village). Eudominant species of the Veporské

$\mathrm{T}$ a b le 2. Systematic review of recorded species of Carabid beetles (Carabidae).

\begin{tabular}{|c|c|c|c|c|c|c|}
\hline \multirow{2}{*}{ Species } & 1 & 2 & 3 & 4 & 5 & 6 \\
\hline & \multicolumn{6}{|c|}{ Number of specimen } \\
\hline Abax parallelepipedus (PILLER \& MITTEPACHER,1783) & 18 & - & 2 & - & 1 & - \\
\hline Anchomenus dorsalis (PONTOPPIDAN, 1763) & - & - & - & - & - & 4 \\
\hline Brachinus crepitans (LINNAEUS,1758) & - & - & - & - & - & 2 \\
\hline Brachinus explodens DUFT, 1812 & - & - & - & 4 & - & - \\
\hline Calathus fuscipes (GOEZER, 1777) & - & - & - & 2 & - & 25 \\
\hline Calathus melanocephalus (LINNAEUS,1758) & - & - & - & 3 & - & - \\
\hline Carabus convexus FABRICIUS, 1775 & 2 & - & - & - & - & - \\
\hline Carabus coriaceus LINNAEUS, 1758 & 1 & - & 3 & 5 & 10 & - \\
\hline Carabus hortensis LINNAEUS, 1758 & 31 & - & 26 & - & 4 & - \\
\hline Carabus nemoralis O. F. MÜLLER, 1764 & 12 & - & - & - & - & - \\
\hline Carabus problematicus HERBST, 1786 & 1 & - & - & - & - & - \\
\hline Carabus scheidleri PANZER, 1799 & - & - & - & - & - & 2 \\
\hline Carabus violaceus LINNAEUS, 1758 & 25 & - & 1 & 1 & - & 4 \\
\hline Drypta dentata (ROSSI,1790) & - & - & - & 1 & - & 1 \\
\hline Harpalus affinis (SCHRANK, 1781) & - & - & - & 1 & - & 2 \\
\hline Harpalus tenebrosus DEJEAN, 1829 & - & - & - & - & - & 1 \\
\hline Leistus ferrugineus (LINNAEUS,1758) & - & - & - & 10 & - & 1 \\
\hline Poecilus cupreus (LINNAEUS, 1758) & - & 2 & - & 2 & - & 5 \\
\hline Pseudoophonus rufipes (DE GEER, 1774) & - & 5 & - & 17 & - & - \\
\hline Pterostichus ovoideus (STURM, 1824) & - & - & - & 1 & - & - \\
\hline$\sum$ specimens & 90 & 7 & 32 & 47 & 15 & 47 \\
\hline$\Sigma$ species & 7 & 2 & 4 & 11 & 3 & 10 \\
\hline
\end{tabular}

Explanatory notes: locality/biotope: Utekáč: 1, Farkaška (culture of Picea abies); 2, Lichovo (pastures); Poltár: 3, Kúpna hora (Carpathian oak-hornbeam forest); 4, Prievranka (pastures); 5,Ladovo (Carpathian turkey oak forest); 6, Vinohradná rovina (fallow field). 
vrchy Mts biotopes with II or III frequency class are Abax parallelepipedus ( $\mathrm{D}=12 \%, \mathrm{~F}=$ $73.3 \%)$, Carabus hortensis $(\mathrm{D}=20.6 \%, \mathrm{~F}=73.3 \%)$ and $\mathrm{C}$. violaceus $(\mathrm{D}=16.6 \%, \mathrm{~F}=73.3 \%)$ belonging to the Carabidae family. These species are linked to all types of forest biotopes, from lowlands to mountain level, yet whilst $C$. violaceus prefers forest biotopes, it also occurs in open habitats. Diversity and equitability of beetles in the studied localities were $\mathrm{H}=1.829$, $\mathrm{e}=0.736$ in locality 1 and $\mathrm{H}=1.917, \mathrm{e}=0.747$ in locality 2 .

Acquired species of the Carabidae family were divided according to Buchar (1893) into two bioindication groups. Group A (78\% of the species) was represented by the highest number of species (Abax parallelepipedus, Carabus convexus, C. coriaceus, C. hortensis, $C$. nemoralis nemoralis, C. problematicus and C. violaceus. Group E (22\% of the species) was represented by the species Poecilus cupreus cupreus and Pseudoophonus rufipes. P. rufipes prefers arable land. In our material, this was represented by a small number of specimens (Table 1). It follows that these species are adaptable, inhabiting natural biotopes or biotopes that are close to a natural state.

We registered 138 specimens of beetles belonging to 28 species and 7 families in localities 3 and 4 (the Juhoslovenská kotlina Basin, Poltár town). Eudominant species with II or III class frequency are P. rufipes (family Carabidae) $(\mathrm{D}=12.3 \%, \mathrm{~F}=40 \%)$ and Carabus hortensis (family Carabidae) $(\mathrm{D}=18.7 \%, \mathrm{~F}=46.6 \%)$. Pseudoophonus rufipes remains in open and dry and also in humid fields and ruderal meadows, at the edge of the forest in the lowlands, up to mountain level. The Carabus hortensis is linked to the forest biotopes of all types, from lowlands to mountain level. Diversity and equitability of beetles were $\mathrm{H}=1.568, \mathrm{e}=0.713$ in locality 3 and $\mathrm{H}=2.725$, $\mathrm{e}=0.857$ in locality 4 . Group $\mathrm{E}$ ( $69 \%$ of the species) was represented by the highest number of species (Buchar, 1893): stenotopic species Brachinus explodens, Calathus fuscipes fuscipes, C. melanocephalus, Drypta dentata, Harpalus affinis, Leistus ferrugineus, Poecilus cupreus cupreus, Pseudoophonus rufipes, Pterostichus ovoideus. Group A was represented by four eurytopic species (31\% of the species): Abax parallelepipedus, Carabus coriaceus, C. hortensis, C. violaceus. It was also recorded that these three species - Calathus fuscipes fuscipes, Harpalus affinis and Pseudoophonus rufipes - prefer arable land (Vician et al., 2010, 2011).

We registered 144 specimens of beetles belonging to 24 species and 11 families in localities 5 and 6 (the Juhoslovenská kotlina basin, Lučenec town). One species of the Carabidae family (Calathus fuscipes fuscipes, $\mathrm{D}=17.36 \%, \mathrm{~F}=20 \%$ ) belong amongst eudominant species with I or II class frequency. The C. fuscipes fuscipes prefers dry habitats without shade, such as meadows and fields in lowlands to mountain level. Diversity and equitability of beetles in the studied localities were $\mathrm{H}=1.096, \mathrm{e}=0.681$ in locality 5 and $\mathrm{H}=2.516, \mathrm{e}=0.854$ in locality 6. We included seven species to the group E (54\% of the species) (Anchomenus dorsalis, Brachinus crepitans, Calathus fuscipes fuscipes, Drypta dentata, Harpalus affinis, Leistus ferrugineus, Poecilus cupreus cupreus) and six species to the group A (46\% of the species) (Abax parallelepipedus, Carabus coriaceus, C. hortensis, C. scheidleri, C. violaceus, Harpalus tenebrosus,). Almost all of them were eurytopic. We recorded three species that prefer arable land: Anchomenus dorsalis, Calathus fuscipes fuscipes and Harpalus affinis.

We found variability of species data (gradient length of the 1st ordination axis $=4.258$ ) by detrended correspondence analysis (DCA). Spatial analysis of species and localities was 


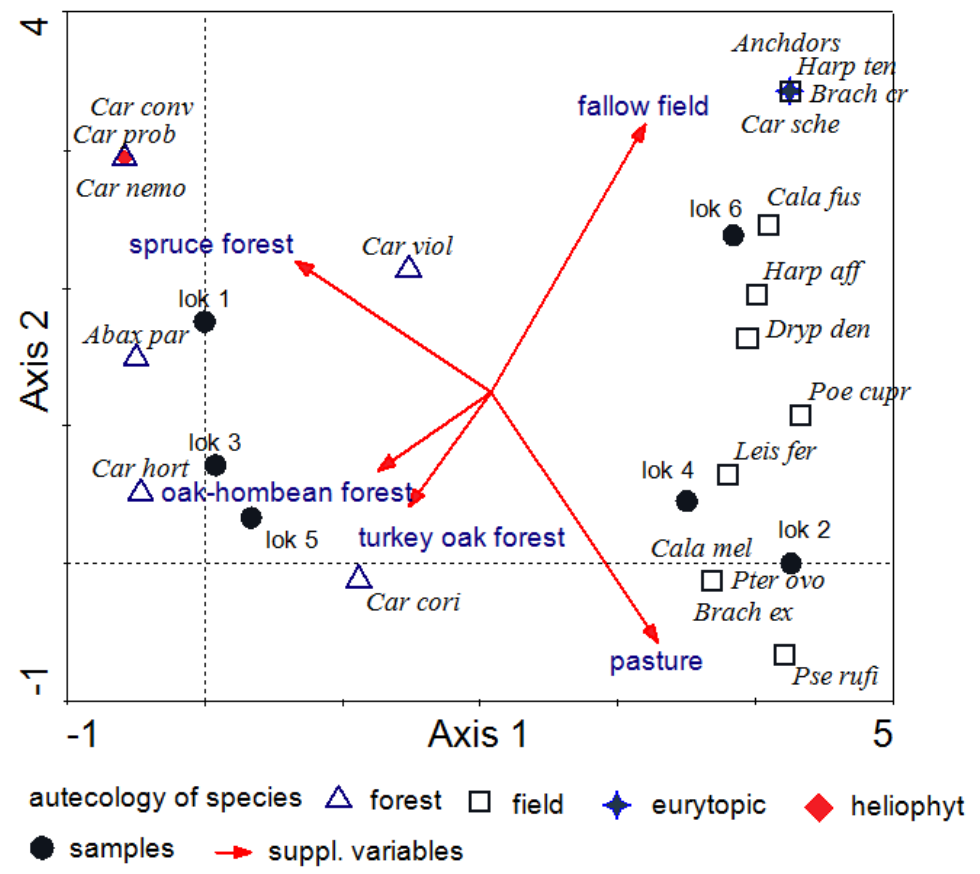

Fig. 1. Triplot DCA, types of biotopes are passive (supplementary) variables Explanatory notes: locality/biotope: Utekáč: loc 1 - Farkaška (culture of Picea abies), loc 2 - Lichovo (pastures); Poltár: loc 3 - Kúpna hora (Carpathian oak-hornbeam forest), loc 4 - Prievranka (pastures), loc 5 - Ladovo (Carpathian turkey oak forest), loc 6 - Vinohradná rovina (fallow field).

shown by DCA (Fig. 1). Environmental variables (biotopes) were used as additional (supplementary) variables. We investigated the correlation of the Carabidae family species to the types of biotopes by canonical correspondence analysis (CCA). With forest biotops (locality 1 Farkaška (culture of Picea abies); locality 3 Kúpna hora (Carpathian oak-hornbeam forest) and locality 5 Ladovo (Carpathian turkey oak forest)), correlate the species Abax parallelepipedus, Carabus convexus, C. coriaceus, C. hortensis, C. nemoralis, C. problematicus and C. violaceus. With biotops of the open areas (locality 2 Lichovo (pastures); locality 4 Prievranka (pastures) and locality 6 Vinohradná rovina (fallow field)), correlate the species Anchomenus dorsalis, Brachinus crepitans, B. explodens, Calathus fuscipes, C. melanocephalus, Carabus scheidleri, Drypta dentata, Harpalus affinis, H. tenebrosus, Leistus ferrugineus, Poecilus cupreus, Pseudoophonus rufipes and Pterostichus ovoideus. Characteristic species of arable land according to the classification of Vician et al. $(2010,2011)$ were recorded in a fallow field (locality 6 Vinohradná rovina Flatland) - Anchomenus dorsalis, Calathus fuscipes fuscipes and Harpalus affinis - and in pastures (locality 2 Lichovo; locality 4 Prievranka) Calathus fuscipes fuscipes, Harpalus affinis and Pseudoophonus rufipes. These types confirm agricultural land use at the locality of the Vinohradná rovina and its contact area. We proved statistically important correlation (Spearman, $\mathrm{p}_{\alpha}=0.05$ ) amongst the species characteristic 
Table 3. Statistically important correlation of the species (Spearman $r$ coefficient, $p_{\alpha}<0.05$ ).

\begin{tabular}{|l|c|c|c|}
\hline & Calathus fuscipes & Drypta dentata & Harpalus affinis \\
\hline Calathus fuscipes & - & & \\
\hline Drypta dentata & 0.979 & - & \\
\hline Harpalus affinis & - & 0.979 & 0.920 \\
\hline Leistus ferrugineus & 0.920 & 0.979 & 0.821 \\
\hline Poecilus cupreus & 0.821 & - & \\
\hline
\end{tabular}

for arable soil. (Table 3). Carabus problematicus is rated as an important indicator of natural preservation of the forest ecosystems. Its occurrence was recorded in the locality 1 Farkaška. DCA shows high values of explained species variability. The gradient represented by the 1st axis explains $43.9 \%$ of total species variability. Similarly, some species variability explained by environment variables is high $(49.5 \%)$. It should be mentioned that the total 'represented' by the ordination model is only $1.85 \%$. We confirmed that fallow field (p-value $=0.038$ ) is a statistically important type of biotope $(\mathrm{p}=0.05)$ and pasture biotope had a $\mathrm{p}$-value of 0.06 . We found statistically important correlation (Spearman, $\mathrm{p}_{\alpha}=0.05$ ) amongst biotops, Carpathian oak-hornbeam forest and Carpathian turkey oak forest according to the importance $r=0.885$, the maximum inflation factor $=1.35$. The statistical significance of other types of biotopes has not been confirmed, which was expected. We assume that this was due to the lower amount of species richness that was captured.

In the study localities, the Carabidae family was represented mostly by species that prefer open habitats, namely, macropterous and brachypterous species. Species inhabiting stable ecosystems (forests) have lost their flight ability unlike species inhabiting ecosystems that are exposed to cyclic oscillation of some factors of the environment, or directly to stress. In this case, flight ability is essential for the success of the species (Porhajašová, Šustek, 2011). We recorded the most airworthy species in the following localities: Vinohradnícka rovina field (Juhoslovenská kotlina basin) and Prievranka - pastures (of Juhoslovenská kotlina basin). The domination of these species indicates instability of the monitored ecosystems as an outcome of increased antropogenic intervention in these area.

An important indicator of natural preservation of forest ecosystems is the species C. problematicus, which is listed in the Red list of Slovakian beetles (Holecová, Franc, 2001) in the group LR: cd (dependent on protection). The species inhabits much of Europe - though predominantly Western Europe. In the north, it extends to the Arctic Circle and is abundant throughout the British Isles (England, Wales, Scotland and Ireland). It prevails from June to September in mostly dry and open coniferous forests. It is absent in the lowlands. Its local occurrence in Slovakia was recorded in the Malá Fatra Mts, Strečno village, Ponitrie-Sokolec Mts, the Žiar nad Hronom town (Majzlan, 1999) and the Velká Fatra Mts (Franc, 2002).

\section{Conclusion}

In the forest localities, we recorded the highest value of beetle diversity $(H=1.829)$ in the Farkaška locality, which is least affected by human activity. We recorded the lowest value of diversity $(\mathrm{H}=1.096)$ in the Lichovo locality because of ongoing intensive logging. Equitabil- 
ity was in the range from $\mathrm{e}=0$ to $\mathrm{e}=1$, balanced communities were close to 1 . The highest value of equitability was in the Farkaška locality $(e=0.736)$ with eudominant species $C$. hortensis and C. violaceus, the lowest was in the Ladovo locality $(\mathrm{e}=0.681)$.

In open spaces, we recorded the highest value of beetle diversity $(\mathrm{H}=2.725)$ in the Prievanka locality. This locality is affected by agricultural activity (cultivated land) with the following confirmed species that are related to cultivated land: Anchomenus dorsalis, Calathus fuscipes fuscipes, Harpalus. affinis and Pseudoophonus rufipes. The lowest value of diversity $(\mathrm{H}=1.917)$ was recorded in the Lichovo locality. This locality was affected by cattle grazing and degradation of vegetation cover to which herbivore beetle species are linked. The highest value of equitability was in the Prievranka locality $(e=0.857)$ represented by the eudominant species $P$. rufipes, whilst the lowest was in the Lichovo locality $(\mathrm{e}=0.747)$.

From the Carabidae family, we recorded a predominance of eurytopic species, unstable species, and changing habitats in the Juhoslovenská kotlina Basin. Adaptive species living in natural habitats or habitats that are similar to natural habitats were predominant in the Veporské vrchy Mts. These included species inhabiting areas that are moderately influenced by human activity, mostly species in cultural forests and also species in unregulated, untouched river banks. Agriculture is not developed in the Veporské vrchy Mts region, but in nearby forests, there is ongoing forest harvesting. Typical species of arable lands from the Carabidae family were Anchomenus dorsalis, Calathus fuscipes fuscipes, Harpalus affinis and Pseudoophonus rufipes, occurring mainly in the Juhoslovenská kotlina basin. There was only one species - P. rufipes - in the Veporské vrchy Mts region, which was represented by a small number of specimens. This species prefers arable land, but it also inhabits open habitats (meadows, ruderals, forest edges).

In the Juhoslovenská kotlina basin, the Carabidae family was represented mainly by macropterous species. Their presence points to unstable changing ecosystems in the study areas as a result of developed agriculture. In the Veporské vrchy Mts region, there was a predominance of adaptable species, which points to less disturbed ecosystems in the study area, which also confirms the presence of the Carabus problematicus species, which is an important indicator of the natural preservation of forest ecosystems.

Acknowledgements

This article was supported by grant VEGA no. 1/0109/13 and VEGA no. 1/0496/16.

\section{Appendix}

The explanation of the Carabidae species used in detrended coordinated coordination analyse (DCA): Abax par, Abax parallelepipedus; Anch dors, Anchomenus dorsalis; Brach cr, Brachinus crepitans; Brach ex, Brachinus explodens; Cala fus, Calathus fuscipes; Cala mel, Calathus melanocephalus; Car conv, Carabus convexus; Car cori, Carabus coriaceus; Car hort, Carabus hortensis; Car nemo, Carabus nemoralis; Car prob, Carabus problematicus; Car schre, Carabus scheidleri; Car viol, Carabus violaceus; Dryp den, Drypta dentata; Harp aff, Harpalus affinis; Harp ten, Harpalus tenebrosus; Lesi fer, Leistus ferrugineus; Poe cupr, Poecilus cupreus; Pse rufi, Pseudoophonus rufipes; Pter ovo, Pterostichus ovoideus. 


\section{References}

Balthasar, V., Bouček, Z., Günther, V., Šedivý, J. \& Pelikán J. (1957). Klič zvíreny ČSR. Praha: Československá akademie věd. Baranová, B. \& Jászay T. (2010). K poznaniu epigeickej fauny chrobákov (Coleoptera) Jedlobučín Čergovského pohoria. Folia Faunistica Slovaca, 15(13), 105-117.

Buchar, J. (1893). Klasifikace druhu pavouči zvířeny Čech jako pomůcka k bioindikaci kvality životního prostredí. Fauna Bohemiae Septentrionalis, 8, 119-135.

Burgio, G., Campanelli, G., Leteo, F., Ramilli, F., Depalo, L., Fabbri, R. \& Sgolastra F. (2015). Ecological sustainability of an organic four-year vegetable rotation system: Carabids and other soil arthropods as bioindicators. Agroecology and Sustainable Food Systems, 39(3), 295-316. DOI: 10.1080/21683565.2014.981910.

Finch, O.D. (2005). Evaluation of mature conifer plantations as secondary habitat for epigaeic forest arthropods (Coleoptera: Carabidae; Aranae). For. Ecol. Manag., 204, 23-36. DOI: 10.1016/j.foreco.2004.07.071.

Franc, V. (1995). On beetles (Coleoptera) of Cerová vrchovina mts. With special referrence to bioindicatively significant species (in Slovak). In A. Krištín \& K. Gaálová (Eds.), Rimava 1995 (pp. 52-70). Banská Bystrica: SAŽP.

Franc, V. (2002). Beetles (Coleoptera) of the Vel'ká Fatra Mts with special reference to bioindicatively significant species. Matthias Belivs University Proceedings, 2(Suppl. 1), 165-177.

Freedman, B., Zelazny, V., Beaudette, D., Fleming, T., Johnson, G., Flemming, S., Gerrow, J.S., Forbes, G. \& Woodley S. (1996). Biodiversity implications of changes in the quantity of dead organic matter in managed forests. Environ. Rev., 4, 238-265. DOI: 10.1139/a96-013.

Hammer, Ø. (2015). Past paleontological statistics version 3.05. Reference manual (CD). University of Oslo: Natural History Museum.

Halpern, C.B., McKenzie, D., Evans, S.A. \& Maguire D.A. (2005). Initial responses of forest understories to varying levels and patterns of green-tree retention. Ecol. Appl., 15, 175-195. DOI: 10.1890/03-6000.

Holecová, M. \& Franc V. (2001). Red list of plants and animals of Slovakia nature conservation (in Slovak). Ochrana Prírody, 20 (Suppl.), 111-128.

Hulcr, J. \& Mccoy N. (2015). Catching beetles. http://www.ambrosiasymbiosis.org/ambrosia-beetles/catching-beetles/.

Hůrka, K. \& Šustek Z. (1995). Coleoptera: Caraboidea. Folia Fac. Sci. Nat. Univ. Masaryk. Brun. Biol., 93, 349-365.

Hůrka, K. (1996). Carabidae of the Czech and Slovak Republics. Zlín: Kabourek.

Igondová, E. \& Majzlan O. (2015). Assemblages of ground beetles (Carabidae, Coleoptera) in peatland habitat, surrounding dry pine forests and meadows. Folia Oecologica, 42(1), 21-28.

Kalivoda, H., Petrovič, F., Kalivodová, E. \& Kürthy A. (2010). Influence of the landscape structure on the butterfly (Lepidoptera, Hesperioidea and Papilionoidea) and bird (Aves) taxocoenoses in Vel'ke Levare (SW Slovakia). Ekológia (Bratislava), 29(4), 337-359. DOI: 10.4149/ekol_2010_04_337.

Kleinert, J. (1985). Contribution to the knowledge of ground beetles Coleoptera: Carabidae in the protected territory Muránska Planina (in Slovak). Ochrana Prírody, 6, 282-292.

Losos, B., Gulička, J., Jellák, J. \& Pelikán J. (1984). Ekologie živočichů. Praha: SPN.

Lövei, G. \& Sunderland K. (1996). Ecology and behavior of ground beetles (Coleoptera: Carabidae). Annu. Rev. Entomol., 41, 231-256. DOI: 10.1146/annurev.en.41.010196.001311.

Majzlan, O. (1999). Chrobáky (Coleoptera) v okolí priemyselného centra hlinikárne Žiar nad Hronom. Folia Faunistica Slovaca, 4, 111-120.

Majzlan, O. (2010). Obraz fauny chrobákov (Coleoptera) v PR Suché doly (NP Muránska planina). Naturae Tutela, 14(1), 15-27.

Nietupski, M., Kosewska,A., Markuszewski, B. \& Sądej W. (2015). Soil management system in hazelnut groves (Corylus sp.) versus the presence of ground beetles (Coleoptera: Carabidae). J. Plant Prot. Res., 55(1), $26-34$.

Novák, K., Balát, F., Bartoš, E., Bouček, Z., Daniel, M., Dlabola, J., Doskočil, J., Holman, J., Hrbáček, Jagemann, E., Kunst, M., Landa, V., Lang, J., Mařan, J., Miller, F., Nosek, J., Novák, K., Obenberger, J., Obr, S., Pelikán, J., Raušer, J., Rosický, B., Rusek, J., Schwarz, J., Skuhravý, V.,Slouková, M., Šilhavý, V., Štys, P., Teyrovský, V., Vondráček, K., Zahradník, J. \& Zelenský J. (1969). Metódy sběru a preparace hmyzu. Praha: Academia.

Porhajašová, J., Petřvalský, V., Urminská, J., Noskovič, J. \& Molnárová J. (2008). The evaluation of bioindicators abilities of selected zoocoenosis (Carabidae, Coleoptera) in dependence on different farming systems (in Slovak). In Environmental protection and food safety in crop production (pp. 262-266). Debrecen.

Porhajašová, J. \& Šustek Z. (2011). Priestorová štruktúra spoločenstiev bezstavovcov s dôrazom na čelad’ Carabidae v prírodnej rezervácii Žitavský luh. Nitra: SPU.

Ružičková, H., Halada, L., Jedlička, L. \& Kalivodová E. (1996). Biotopy Slovenska. Bratislava: ÚKE SAV. 
StatSoft, Inc. (2009). STATISTICA (data analysis software system), version 9.0. www.statsoft.com.

Šteffek, J., Gallay, I., Gallayová, Z., Kunca, V., Lepeška, T., Olah, B., Škvareninová, J., Ujházyová, M., Wiezik, M. \& Križanová Z. (2008). Krajinnoekologický výskum. Zvolen: TU.

Ter Brak, C.J.F., Šmilauer, P. (2002). CANOCO Reference Manual and User's Guide to Canoco and CanoDraw for Windows User's Guide: Software for Canonical Community Ordination (version 4.5). Ithaca NY: Microcomputer Power.

Topping, Ch., Craig, P., Jong, F., Klein, M., Laskowski, R., Manachini, B.,Pieper, S., Smith, R., Sousa, J., Streissl, F., Swarowsky, K., Tiktak, A. \& Linden T. (2015). Towards a landscape scale management of pesticides: ERA using changes in modelled occupancy and abundance to assess long-term population impacts of pesticides. Sci. Total Environ., 537(15), 159-169. DOI: 10.1016/j.scitotenv.2015.07.152.

Vician, V., Stašiov, S., Kočík, K. \& Hazuchová L. (2007). Štruktúra chrobákov (Coleoptera, Carabidae) na rôzne obhospodarovaných polnohospodárskych plochách. In D. Daniš (Ed.), Vplyv foriem obhospodarovania polnohospodárskej krajiny na základné zložky agroekosystémov vo vztahu k optimalizácii využivania krajiny (pp. 67-77). Poníky.

Vician, V., Stašiov, S., Kočík, K. \& Hazuchová L. (2008). Vplyv rôzneho polnohospodárskeho manažmentu na spoločenstvá chrobákov (Coleoptera, Carabidae) v Podpolaní. In T. Benčat', P. Jančura \& D. Daniš (Eds.), Vybrané problémy krajiny podhorských a horských oblastí (pp. 93-107). Poníky.

Vician, V., Stašiov, S., Kočík, K. \& Hazuchová L. (2010). Carabidae (Coleoptera) structure on variously managed agricultural land of Podpolanie area (in Slovak). Acta Facultatis Ecologiae, 22, 133-146.

Vician, V., Stašiov, S., Kočík, K. \& Hazuchová L. (2011). Structure of the Carabids (Coleoptera: Carabidae) associations on variously managed agricultural land of Podpolanie area and their bioindication (in Slovak). Acta Facultatis Ecologiae, 24-25, 123-131. 